\title{
EFEKTIFITAS PEMANFAATAN MEDIA GAME DOBE FLASH UNTUK MELATIH KEMAMPUAN INTERAKSI SISWA AUTISME
}

\author{
Dewi Rayani ${ }^{1}$ dan Wiwiek Zainal Sri Utami ${ }^{2}$ \\ Bimbingan dan Konseling, FIP IKIP Mataram \\ Basmarayani@yahoo.com
}

\begin{abstract}
Abstrak : Autisme merupakan gangguan perkembangan yang ditandai dengan kegagalan dalam interaksi, komunikasi dan perilaku. Anak dengan gangguan ini dikatakan hidup dalam dunianya sendiri. Salah satu penanganan autisme dengan pemberian terapi. Adapun materi yang ada dalam teripi ini dikemas dalam bentuk game adobe flash. Adapun tujuan penlitian ini adalah untuk mengetahui efektifitas game adobe flash untuk melihat kemampuan interaksi pada anak autisme. Penelitian ini menggunakan metode ekperimental dengan one group , pretest-posttest desain. Populasi dalam penelitian ini adalah 3orang siswa autisme di SLB Pembina Provinsi NTB. Pengambilan data dalam penelitian ini dengan observasi dengan uji statistic Wilcoxon march pairs tes. Adapun hasil yang didapatkan adalah signifikan hal ini ditunjukkan berdasarkah adanya perbedaan nilai pretes dan posttest dengan taraf signifikansi 5\%. Dengan demikian kesimpulan dari penelitian ini adalah bahwa penerapan game adobe flash sangat efektif untuk melatih kemampuan interaksi siswa autime.
\end{abstract}

Kata Kunci: Media Game Dobe Flash, Autisme

\section{LATAR BELAKANG}

Autisme merupakan gangguan perkembangan pada anak yang ditandai dengan adanya kegagalan dalam aspek interaksi, komunikasi dan perilaku (Triantoro, 2005). Anak dengan gangguan autisme kesulitan untuk memahami apa yang dipikirkan dan dirasakan orang lain oleh karena itu, anak dengan gangguan ini dikatakan tidak memiliki empati. Selain itu anak autisme memiliki kesulitan mengekspresikan diri baik dalam ekpesi wajah serta sentuhan. Kesulitan anak dalam mengepresikan diri ini membuat anak selalu hidup dalam dunianya sendiri, selalu menarik diri dalam lingkungan sosial dan enggan untuk berinteraksi dengan sesama.

Perilaku menarik diri yang dialami anak autisme akan cendrung berkurang dikala anak autisme sudah memasuki usia sekolah. Karena di sekolah anak diajarkan berbagai hal, seperti meatih kemampuan bantu diri, kemampuan bicara, kemampuan konsentrasi serta kemampuan kontak mata yang merupakan aspek awal untuk memulai interaksi dengan individu yang lain. Dengan bersekolah atau melakukan terapi secara rutin diharapkan dapat merubah berbagai kelemahan yang dimiliki siswa autisme tersebut.

Sebagaimana halnya ganggu yang dialami anak autisme adalah pada aspek interaksi sosial yang menyebabkan anak tersebut tidak dapat beradaptasi dan bergaul secara baik dan tidak dapat melakukan hubungan sosial ( Handojo, 2009) adanya gangguan interaksi sosial ini akan mempengaruhi anak dalam segi belajar dan berperilaku, anak autisme sering kali mengasingkan diri walaupun dalam situasi kelas yang ramai (Handojo, 2009).

\section{KAJIAN PUSTAKA}

Interaksi sosial adalah dimana seseorang memperoleh kemampuan untuk menyesuaikan diri dengan tuntutan sosial (Selamet,2010). Interaksi juga merupakan tindakan yang dilakukan oleh seseorang yang menjadi stimulus bagi tindakan individu lain yang menjadi peransangnya (Ali, 2004). Interaksi sosial menjadi aspek yang sangat penting bagi anak, karena masa anak-anak masih dalam masa bermain yang membutuhkan orang lain dalam proses interaksinya. Adapun interaksi sosial ini terdiri dari empat faktor ekternal penting yaitu imitasi, sugesti, identifikasi dan empati. (Bambang, 2015) dengan terpenuhinya empat faktor ini maka anak dikatakan suskses dalam melakukan interaksi.

Dalam melatih kemampuan interaksi bagi anak autisme dilakukan beberapa terapi, salah satu diantaranya adalah dengan terapi 
ABA (appliet Behaviour analysis (yuwono,2009)) adapun metode yang diterapkan pada terapi ini adalah melatih kontak mata, berbicara dan berinteraksi sosial. Penerapan terapi ini diharakan dapat memperbaiki beberapa kelemahan siswa autime. Dan pada saat sekarang ini pesatnya laju ilmu dan teknologi memberikan stimulus bagi setiap orang untuk melakukan pengembangan ilmu pengetahuan terutama dalam bidang pendidikan dan pengajaran.

Salah satu produk ilmu teknologi yang bisa dijadikan untuk mengembangkan media pembelajaran adalah dengan software Adobe Flash. Software ini diaplikasikan dengan komputer, yang mana komputer adalah alat yang sering digunakan untuk mengembangkan berbagai media pembelajaran. Dengan menggunakan software Adobe Flash dapat dibuat media pembelajaran berbasis teknologi multimedia komputer. Kemampuan program Adobe Flash dalam membuat prsentasi multimedia mendukung membuat animasi secara langsung, mendukung penyisipan multimedia seperti sound, gambar dan kemudahan pengoperasiannya. Dalam penelitian ini, beberapa treatment dan teori yang diterapkan dalam terapi ABA telah dikemas dalam multi media computer dengan menggunakan media adobe flash. Adapun materi yang disisipkan dalam pembuatan media ini adalah diadopsi berdasarkan Metode appliet Behaviour analysis yang dikemas dalam software adobe flas yang menarik. Dasar dari metode ini menggunakan teori behavioral, yang menekankan kepatuhan, keterampilan anak dalam meniru, membangun kontak mata dan komunikasi. Dengan adanya beberapa penekanan ini maka akan terbentuk interaksi antar guru dengan siswa. Dengan inilah siswa autisma yang memiliki kegagalan dalam aspek interaksi dan komunikasi dilatih untuk memperbaiki berbagai kegagalan yang ada tersebut yaitu terus diajarkan untuk berinteraksi dengan orang lain melalui permaina yang menyenangkan.

Paweni (dalam wiwik,2015) dalam penelitiannya membahas software Game
Adobe Flash merupakan program yang dirancang khusus untuk anak-anak dengan kebutuhan khusus dan cara-cara orang tua dan guru untuk membantu keberhasilan anak. Gambar-gambar pada game Adobe Flash dikombinasikan dengan dengan katakata agar dapat membantu anak-anak memperoleh keterampilan membaca dan meningkatkan reseptif dan ekspresif kosakata.

\section{METODE PENELITIAN}

$$
\text { Penelitian ini mengunakan }
$$

pendekatan kuntitatif preekperimen dengan bentuk one grup pretest desain karena pada pnelitian ini tidak menggunakan variable control dan terdapat pretest sebelum dilakukan perlakuan dengan menggunakan kelompok ekerimen yang bertujuan untuk hasil dari perlakukan yang lebih akurat. Berikut gambar disain penlitian ini (Sugiono, 2016)

\section{$\mathrm{O} 1 \times 02$}

Keterangan :

OI : Pretest merupakan awal bagaimana anak dapat melakukan interaksi dengan menerapkan beberapa komponen-komponen imitasim identifikasi serta sugesti pada anak autisme sebelum diberikan perlakuan dengan media game adobe flash yang dilakukan sebayak 2 kali.

X : $\quad$ Treatmen dengan menerapkan media game, perlakukan diberikan sebanyak 5 kali pertemuan

O2: Posttest, diberikan untuk melihat perubahan kemampuan interaksi pada anak autisme setelah diberikan perlakuan dengan media game adobe flash.

Populasi Dan Sampel

Populasi pada penlitian ini adalah siswa SLB Pembina Provensi NTB sedangkan sampel dalam penelitian ini diambil 3 orang siswa yang ada di SLB Provinsi NTB dengan kriteria gangguan autisme yang masih memiliki kegagalan 
dalam interaksi komunikasi. Adapun sampel

berikut

tersebut dapat diidentifikasi pada table

Tabel 01: Data Nama Subjek Penelitian Siswa Autisme Di SLB Pembina Provinsi NTB

\begin{tabular}{|c|l|c|}
\hline No & Nama siswa & Jenis kelamin \\
\hline 1 & AN & Laki-laki \\
\hline 2 & BG & Laki-laki \\
\hline 3 & CI & Perempuan \\
\hline
\end{tabular}

\section{DEFINISI OPRASIONAL}

- Media Geme Adobe Flash(dahulu bernama Macromedia Flash) adalah salah satu perangkat lunak komputer yang merupakan produk unggulan Adobe Systems. Adobe Flash digunakan untuk membuat gambar vektor maupun animasi gambar tersebut. Secara oprasional yang dimaksud dengan media game adalah penyampaian materi yang ada dalam game ini menggunakan anroid. Media yang memberikan unsure game yang menarik terhadap kemampuan interaksi siswa autisme yang didasarkan pada faktor eksternal dalam interaksi sosial.

- Interaksi sosial adalah hubungan antar manusia yang menghasilkan proses saling mempengaruhi yang menghasilkan hubungan tetap dan pada akhirnya memungkinkan terentuknya struktur sosial. Handayani (dalam bambang, 2015). Ahli lain juga berpendapat tentang interaksi sosial Menurut Bonner ( dalam Ali, 2004) merupakan suatu hubungan antara dua orang atau lebih individu, dimana kelakuan individu mempengaruhi, mengubah atau mempengaruhi individu lain atau sebaliknya.

- Autisme merupakan gangguan perkembangan pervasive yang ditandai dengan adanya gangguan perkembangan psikologi dasar majmuk meliputi perkembangan keterampilan sosial dan bahasa seperti perhatian, persepsi, nilai terhadap realita dan gerak-gerak motorik serta terjadinya kegagalan dalam interkasi , komunikasi dan perilaku ( Triantoro, 2005)

\section{TEKNIK PENGUMPULAN DATA}

Teknik pengumpulan data merupakan langkah yang paling utama dalam penelitian, karena tujuan utama dalam penelitian adalah mendapatkan data (Sugiono, 2013). Adapun dalam penelitian ini teknik pengumpulan data yang digunakan dengan tes, Arikunto ( 2010) metode tes merupakan sederetan pernyataan atau latihan serta alat lain untuk mengukur keterampilan, intelegensi, keterampilan bakat individu atau kelompok. Tes dalam penelitian ini meliputi pretest dan posttest untuk mengukur perubahan yang terjadi terhadap kemampuan interaksi siswa autime, walaupun dalam hal ini sudah jelas bahwa anak autisme memiliki kegagal dalam aspek interaksi dan komunikasi. Penelitian ini dilakukan dalam 8 kali petemuan dengan rincian dua kali pertemuan untuk pretest dan lima kali pertemuan untuk treatmen dan satu kali untuk posttest. Tes yang dilakukan pada tahap akhir menggunakan observasi secara langsung dengan menceklis beberapa komponen yang dinilai.

\section{TEKNIK ANALISA DATA}

Analisa data dalam penelitian ini menggunakan analisa ststistik non parametric dikarenakan jumlah sampel yang diteliti kurang dari 30 siswa yaitu $n=3$ yang dikatakan dengan sampel kecil. Penelitian ini juga menggunakan uji jenjang bertanda Wilcoxon march pairs tes.

\section{HASIL PENELITIAN}




\section{DATA HASIL PRE-TEST}

Hasil pretest merupakan nilai kemampuan interaksi sosial yang meliputi kemampuan imitasi, melabel, identifikasi dan kemampuan memperhatikan sebelum mendapatakan perlakuan. Pada tahapan ini peneliti memberikan game untuk menilai berbagai kemampuan yang dimiliki anak autisme dengan hasil nilai yang didapatkan melalui diobservasi dan menceklis beberapa kemampuan yang terlihat pada saat game ini diberikan. Berikut hasil pretest terhadap kempuan interaksi siswa autisme.

Table 02 : Nilai Hasil Pretest Kemampuan Interaksi Sosial Siswa Autisme Di SLB Pembina Provinsi NTB

\begin{tabular}{|c|l|c|}
\hline No & \multicolumn{1}{|c|}{ Nama } & Nilai Hasil Pre Test \\
\hline 1. & AN & 2,58 \\
\hline 2. & BG & 2,85 \\
\hline 3. & CI & 2.72 \\
\hline \multicolumn{2}{|c|}{ Rata-tara } & $\mathbf{8 , 1 5 5 : 3 = 2 , 7 1}$ \\
\hline
\end{tabular}

\section{DATA HASIL POSTTEST}

Hasil posttest merupakan hasil nilai kemampuan interkasi siswa autisme setelah diberikan perlakuan berupa pembelajaran menggunakan media game adobe flash dalam bentuk miromedia dengan menggunakan laptop yang dilakukan sebanyak lima kali dalam proses pembelajaranya dan ditambah satu kali posttest hasil posttest didapatkan juga dengan menobservasi berbagai perilaku yang di nilai sebagai observasi penilaian denga rincian kemampuan yang dinilai adalah kemampuan imitasi, identifikasi, memberikan label dan melatih perhatian. Berikut hasil penilaian posttest yang dapat dilihat pada table dibawah ini.

Table 03 : Hasil Nilai Posttest Siswa Autisme Terhadap Efektifitas Penggunaan Game Adobe Falsh Terhadap Kemampuan Intreraksi Siswa Autisme

\begin{tabular}{|c|c|c|}
\hline NO & NAMA SISWA & HASIL POSTTEST \\
\hline 1. & AN & 4.00 \\
\hline 2. & BG & 4.07 \\
\hline 3. & CI & 4.12 \\
\hline \multicolumn{2}{|c|}{ Rata-Rata } & $\mathbf{1 2 , 1 9 : 3 = 4 . 0 6}$ \\
\hline
\end{tabular}

ANALISA DATA

Berdasarkan hasil penelitian terhadap kemampuan interaksi siswa autime dengan menggunakan game adobe flash sebelum dan sesudah diberikan perlakuan, kemudian dianalisa dengan statistic non parametric menjawab rumusan masalah dan menguji hipotesis yang berbunyi " ada perbedaan antara kemampuan interaksi siswa autime setelah pemberian media game adobe flash" berikut langkah langkah yang dilakukan dalam analisa data: Membuat table kerja analisa data yang digunakan untuk menguji perubahan hasil tes akhir dan observasi awal terhadap kemampuan interaksi siswa autisme menunjukkan $\mathrm{T}$ ( jumlah jenjang) sebagaimana ditunjukkan dalam table sebagai berikut

Tabel 04: Perubahan Hasil Tes Awal Dan Tes Akhir Kemampuan Interaksi Sosial Siswa Autima Dengan Perlakuan Game Adobe Flash di SLB Pembina Provinsi NTB

\begin{tabular}{|c|c|c|c|c|}
\hline \multirow{2}{*}{ No } & \multirow{2}{*}{ Inisial Nama } & \multicolumn{2}{|c|}{ Nilai } & Perubahan \\
\cline { 3 - 4 } & Pretest & Posttest & tanda \\
\hline
\end{tabular}




\begin{tabular}{|l|l|l|l|l|}
\hline 1. & AN & 2,58 & 4,00 & + \\
\hline 2. & BG & 2,85 & 4,07 & + \\
\hline 3. & CI & 2,75 & 4,12 & + \\
\hline \multicolumn{4}{|c|}{ Jumlah Tanda Plus (+) } \\
\hline
\end{tabular}

\section{PENGUJIAN HIPOTESIS}

Berdasarkan analisa diatas maka hipotesis pada hasil perhitungan dengan nilai krisis $5 \%$ karena dalam penelitian ini untuk mengetahui ada atau tidak perbedaan variable $\mathrm{X}$ dengan variable $\mathrm{Y}$ maka $\alpha 5 \%$ $=1,96$ adalah

$\mathrm{H} 0$ ditolak apabila $\mathrm{Z}$ hitung $>\mathrm{Z}$ table $5 \%=1$, 96

H0 diterima apabila ZHitung $\leq \mathrm{Z}$ table $5 \%=1$, 96

\section{INTERPRETASI DATA}

Berdasarkan hasil analisa data diatasmenujukkan uji non parametric dengan uji peringkat tanda dan data yang ditampilkan memiliki subjek yang kecil yakni kurang dari 30 orang subjek maka hasil $\mathrm{zh}=2,20 \quad$ (Nilai (-) tidak diperhiyungkan karena harga mutak) lebih besar dari nilai $\mathrm{Z}$ table $(\mathrm{Zt})$ dengan nilai kritis 5\%=1.96 maka dapat disimpulkan bahwa zh lebih besar daripada zt dengan semikian $\mathrm{HO}$ ditolak dan Ha diterima . hal ini menujuukkan adanya perbedaan yang signifikan dan efektif antara kemampuan interaksi siswa autisme setelah diberikan atau diterapkan media game adobe flash.

\section{PEMBAHASAN}

Hasil penelitian mengenai efektifitas media game adobe flash untuk melihat kemampuan interaksi siswa autisme di SLB Pembina Provinsi NTB dinyatakan efektif, hal ini dapat dilihat melalui perbedaan hasil pada saat pretest dan pada saat dilakukan posttest. (dalam mudjito, 2011 ) meurut Dodd mengatakan bahwa anak autisme memiliki beberapa kelebihan diantaranya kemampuan dalam rote memory, kemampuan visual spatial kecendrungan untuk melakukan aktifitas yang berulang dan terstruktur dan anak autisme juga termasuk anak visual thingker maka penggunaan media belajar atau game adobe flash ini sangat cocok dan efektif digunakan untuk meningkatkan beberapa kelemahan yang ada dalam diri siswa autisme salah satunya yaitu pada aspek interaksi dengan meliputi adanya kontak mata yang baik ketika game ini diberikan

Kontak mata memang menjadi hal yang sulit bagi siswa autime namun dalam hal ini siswa terus dilatih untuk melakukanya, kegemaran siswa dan ketertarikan siswa terhadap media computer juga memberikan efek yang baik untuk membuat siswa lebih tertarik ketika diberikan game adobe flash. Selain kontakmata kemampuan imitasi juga terlatih dalam hal ini seperti menirukan berbagai gerakan sederhana yang ditampilkan dalam media computer. Denga melihat berberapa adegan dan gerakan, maka secara otomatis anak ikut menirukan gerakan-gerakan yang ada dan tentunya juga dibantu dengan perintah guru yang mengajar.

Selain itu kemampuan mematuhi perintah, ketika guru memberikan perintah yang sesuai dengan apa yang dilihat dalam media, siswa lebih cepat mematuhinya. Dalam media geme adobe flash terdapat pula suara yang disesuaikan dengan intonasi dan kata-kata yang digunakan, misalkan pada kalimat perintah yaitu menggunakan kalimat yang pendek dan mudah difahami. Sedangkan pada aspek komunikasi ini dapat dilihat dan diidentifikasi beberapa aspek komunikasi antara siswa dengan guru yang memberikan game tersebut. Pemberian media ini juga dirasa membuat siswa autisme lebih senang dikarenakan kategori media ini adalah permainan yang meyenangkan dan telah dilakukan uji coba kelayakan dalam pengembanganya.

Hasil penelitian yang menunjukkan adanya peningkatan nilai dari kemampuan interaksi siswa autisme yaitu terlihat dalam kemampuan siswa menirukan dan memperhatikan yaitu dengan rata -rata nilai 
pre tes yaitu 2, 75 dan nilai post test 4, 00 . Dengan demikian adanya game ini dapat dijadikan sebagai media belajar yang baik guna dapat meningkatkan berbagai kelemahan yang ada dalam diri siswa autisme dan game ini dapat dijadikan sebagai media yang menarik dan menyenangkan bagi siswa autisme.

\section{KESIMPULAN}

Hasil penelitian tentang efektifitas game adobe flash untuk melihat kemampuan interaksi siswa autisma di SLB Pembina Provinsi NTB menunjukkan bahwa ada perbedaan kemampuan interaksi siswa setelah diberikan geme adobe flash secara signifikan. Hal ini berdasarkan hasil penelitian sebelum diberikan media game diperoleh nilai rata-rata sebesar 2, 71 dan sesudah diberikan media game adobe flash diperoleh nilai rata-rata sebesar 4.06. selain itu hasil penilaian juga menujukkan bahwa $\mathrm{Zh}=2,20$ lebih besar dari nilai $\mathrm{Z}$ table $5 \%$ yaitu 1,96 yang berarti $\mathrm{zh}>\mathrm{Zt}$ sehingga $\mathrm{HO}$ ditolak dan $\mathrm{Ha}$ diterima artinya ada perbedaan kemampuan interaksi sosial setelah diterapkan media game adobe flah bagi siswa autisme.

\section{DAFTAR PUSTAKA}

Arikunto, Suharsimin, 2010. Prosedur Peneltian Suatu Pendekatan Praktek. Jakarta. PT Rineka Cipta. Jakarta

Bambang, S. Arifin.,2015. Psikologi Sosial. Bandung. Pustaka Setia

Handojo, y., 2009 Autisme pada Anak, Menyiapkan anak Autis untk mandiri dan masuk Sekolah Reguler dengan Metode ABA basic. Jakarta Buana Ilmu Populer.

M. Ali dan Mohammad Asrori, 2004. Psikologi Remaja Perkembangan Peserta Didik. Jakarta Bumi Aksara

Sugiono., 2013 , Metode penelitian kualitatif , Kuantitatif an $R \& D$. Bandung. Alfabeta

Slamet, Santoso., 2010 Teori-Teori Psikologi Sosial. Bandung Refika Aditama

Triantoro, Safaria., 2005. Autisme Pemahaman Baru untuk Hidup Bermakna bagi Orang Tua . Yogyakarta. Garaha ilmu

Wiwik, z. 2015., Pengembangan Modifikasi Game dobe flash jurnal. IKIP Mataram

Yuwono, Joko., 2009. Memahami Autistik. Bandung Alfabeta 